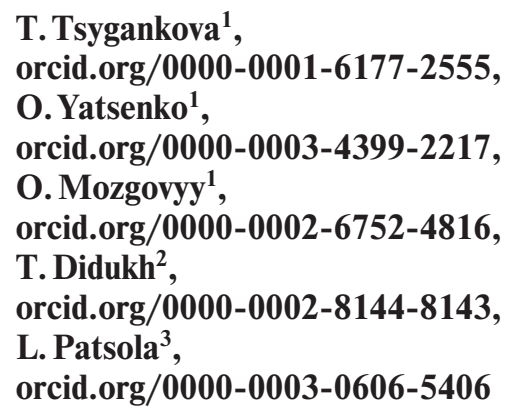

1 - Kyiv National Economic University named after Vadym Hetman, Kyiv, Ukraine, e-mail: yacenkoolgakneu@gmail.com 2 - PPRO Financial Ltd, Munich, the Federal Republic of Germany

3 - CyberVision Inc, Kyiv, Ukraine

\title{
MOBILIZATION OF INNOVATIVE AND RESOURCE FACTORS FOR DEVELOPMENT OF NATIONAL OUTSOURCING IT COMPANIES
}

Purpose. To systematize and justify the mobilization optimization of internal resource potential and innovative indicators for development of national outsourcing IT companies.

Methodology. To complete this paper work the authors followed the justification of the forecast based on the use of the following methods: trend method (establishing the forecast indicators of development on the basis of determining the average trend of the previous periods) to identify and systematize ways to ensure forecast efficiency of resource potential, innovative development of outsourcing companies in IT; comparative and statistical methods (application of methods for analysis of reporting data, their comparison with forecast) and forecasting method (forecasting according to the main quantitative and qualitative indicators) to determine the comparative characteristics of the given paths; geometric method of direct change dependence (determination of the level of change dependence, calculated by the method of direct geometric progression) to assess the forecast scheme for Ukrainian outsourcing IT subjects of unification in the form of cooperation.

Findings. The basic methods of resource potential optimization, innovative indicators for development of outsourcing IT companies in Ukraine are investigated and substantiated. Systematization of scientific approaches, views of researchers allowed forming a list of optimization paths of these companies' development.

Originality. For the first time the organizational and economic form of integration of the subjects of the IT-outsourcing market in Ukraine is proposed as a way to optimize the resource potential of the association in cooperation, which provides functioning of competitive structures based on cooperation and partnership relation with clients, distribution of functional loads, creation of additional market economic effects, possible solution of social and economic problems of regions.

Practical value. The practical significance of the study lies in the development and testing of methodological tools designed for rapid assessment of the development level of innovation and resource potential of IT enterprises. The results of the study can be used by national IT outsourcing companies to increase capital and maintain operational efficiency, to ensure functioning of competitive structures of different categories aimed at increasing the added economic value of their participants.

Keywords: IT outsourcing, information technology (IT), IT outsourcing companies, resource potential of the IT sector

Introduction. The effective functioning of Ukrainian outsourcing IT companies is related to the internal potential of development, in particular, with its resource and innovation opportunities in the future. Successful use of resources and innovative development will ensure sustainable income, profitability and growth (or retention) of market indicators in this area. Management of internal resource and innovation potential requires taking into account external trends in global IT outsourcing. Namely, the activities of the market participants should provide a timely response to the changes in the global, national economies to proceed with retrenchment, reduce costs in the IT field, mobilize their own resources to maintain business interests and develop prospects for further development.

Literature review. Organizational and economic mechanism of innovative development of IT outsourcing is a set of interconnected forms and methods of innovation that contribute to technological modernization of the industry, increase its competitiveness and transform scientific potential into one of the main resources for sustainable economic development of IT.

The goals of the subject of the IT outsourcing market are achieved provided that the resource potential of innovative company development is a system of interconnected optimal resource proportions, both quantitative and qualitative. Therefore, in order to form such a resource potential, it is necessary to manage the process associated with its formation, renewal, development and use.

(C) Tsygankova T., Yatsenko O., Mozgovyy O., Didukh T., Patsola L., 2021
The concept of "resource and innovation potential" in the IT outsourcing market has long been widely discussed on the pages of scientific economic literature. Thus, many domestic and foreign scientists such as A. Altynpara, O. Korogodova [1], A. Verba [2], N. Volkova, O. Kolesnyk, I. Silina [3], N. Meshko, M. Efremova [4] devoted their research work to forecasting the development of IT outsourcing potential at the national level. However, in our opinion, there are no sufficient comprehensive systematic studies that determine the prospects for the effective operation of outsourcing IT companies, considering their resource and innovation capabilities in the future, and the subject of the existing research studies is mainly about the difference between resource and innovation potential, their composition and quantification.

Unsolved aspects of the problem. Despite the significant contribution of scientists to the study on the internal environment of outsourcing IT companies, changes in the socio-economic environment at the global and national levels require generalization and identification of ways to mobilize the internal resource potential of Ukrainian IT outsourcing market. The formation of such methods will allow the business structures to provide effective long-term results in response to external challenges and threats and so on.

Results. Studies on the scientific, analytical research provisions on forecasting the development of the potential of IT outsourcing companies at the national level $[1,2]$ show that the authors mainly focus on a trend-based approach to define longterm values. It is important to note that a consequential aspect of improving the efficiency of resource potential, innovative devel- 
opment is the method for optimizing forecast costs [3, 4], the use of which is associated with maintaining the level or growth of capital, innovative performance of market participants.

Our task now is to consider the best ways to optimize the resource potential, innovative indicators of IT company development in Ukraine, identified by scientists and researchers.

First, it is necessary to note the optimization of development paths associated with cost savings, which are aimed at ensuring resource, innovation, improving functional and organizational management (personnel policy on the functional load of staff, promotion, sales and customer service (customers) and others). These paths are formed as a result of the reaction of the market environment to external socio-economic influences (global financial and economic crisis, the crisis of the national economy, coronavirus, quarantine measures).

Verba's A. approach [2] deserves special attention, within the framework of which the author offers a number of recommendations related to ensuring the efficiency of the resource potential, innovative development of outsourcing companies in the IT field of Ukraine. In Table 1 the authors present the systematization and characteristics of A. Verba's proposals regarding the forecast efficiency of resource potential, innovative development of outsourcing companies in the IT field of Ukraine.

In accordance with the provisions of the considered approach of A. Verba (Table 1), it can be stated that the author identifies the following priority steps:

- a need to preserve the outsourcing company capital in the Ukrainian IT industry by optimizing the functional load on staff (redistribution of tasks in accordance with: relevant working experience; workload per employee) and improving the form of interaction with clients (potential customers) conducting promotion, partnership negotiations in remote forms, active interaction with clients at a time convenient for them;

- a need to maintain or increase the outsourcing companies' capital in Ukraine's IT industry by optimizing indirect costs (reducing rental costs by transferring $30 \%$ of staff to remote work; reducing staff training costs by $65 \%$ );

- possibility of suspending Ukrainian IT outsourcing companies' innovative development in terms of providing training for the forecast financial year. This aspect of optimization, in our opinion, can significantly reduce the level of innovative development of the studied market participants, but it is justified by high experience and the staff's level of education. Certain difficulties could arise when hiring new staff, but A. Verba does not determine the possibility of increasing the number of employees in the field of IT outsourcing in Ukraine.

We should note that the forecast development prospects formulated by A. Verba are quite sound and consistent describing the trends of social-economic external influence like global financial and economic crisis, national economic crisis, coronavirus and quarantine measures in the country or in the world, which affected the main economic processes at all levels and in most of the industries). In our opinion, we could agree with the forecasts' firm justifications regarding the impact of the rental costs reduction on ensuring the maintenance of the corresponding profit of the previous period and the capital of outsourcing companies in the Ukrainian IT indus-

Table 1

Systematization and characteristics of methods to ensure the forecast efficiency of resources potential, innovative development of outsourcing companies in the IT field of Ukraine

\begin{tabular}{|c|c|c|}
\hline No & $\begin{array}{l}\text { Ways to optimize the forecast efficiency of } \\
\text { resources potential, innovative development of } \\
\text { outsourcing companies in the IT field of Ukraine }\end{array}$ & Characteristics of optimization methods \\
\hline 1 & $\begin{array}{l}\text { Maintaining operational efficiency by optimizing } \\
\text { the functional load on staff (ensuring a direct } \\
\text { impact on maintaining net income, net profit and } \\
\text { equity) }\end{array}$ & $\begin{array}{l}\text { Redistribution of tasks in accordance with: } \\
\text { - relevant working experience; } \\
\text { - workload per employee. } \\
\text { Result: ability to ensure high quality for large projects (mainly based on a type of } \\
\text { traditional IT outsourcing (software, including for robotic technology lines), other } \\
\text { types of projects (cloud technology - a new type of IT outsourcing). } \\
\text { Economic result: } 100 \% \text { retention of orders for the main types of IT outsourcing }\end{array}$ \\
\hline 2 & $\begin{array}{l}\text { Maintaining operational efficiency by optimizing } \\
\text { the interaction with clients (potential customers) } \\
\text { (providing a direct impact on maintaining net } \\
\text { income, net profit and equity) }\end{array}$ & $\begin{array}{l}\text { Conducting promotion, partnership negotiations in remote forms, active interaction } \\
\text { with clients at a time convenient for them (applies to customers representatives and } \\
\text { clients from other countries in time zones different from Ukraine). } \\
\text { Economic result: } 100 \% \text { retention of orders for the main types of IT outsourcing, } \\
\text { increase in sales by } 5-10 \%\end{array}$ \\
\hline 3 & $\begin{array}{l}\text { Reduction of indirect costs of outsourcing } \\
\text { companies in the field of IT. Ensuring a direct } \\
\text { impact on net income and equity's growth }\end{array}$ & $\begin{array}{l}\text { The overall effect of the reduction in the two types of costs of outsourcing } \\
\text { companies in the field of IT will be: } 7.5 \% \text { (p. } 3.1 \text { costs for office rent) }+5.2 \% \\
\text { (p. } 3.2 \text { costs for staff training programs) }=12.7 \%\end{array}$ \\
\hline 3.1 & $\begin{array}{l}\text { Reduction of rental costs (by } 30 \% \text { compared to } \\
\text { 2018-2019) }\end{array}$ & $\begin{array}{l}\text { Reduction rental costs by } 30 \% \text { (the estimated percentage of staff transferred to } \\
\text { remote work is } 30 \% \text { in January, February, March, April 2020). } \\
\text { The total share of rental costs among all costs in Ukraine's IT outsourcing was } \\
25 \% \text { in } 2018-2019 \text {. } \\
\text { After reducing rental costs by } 30 \% \text {, this figure (the total share of rental costs } \\
\text { among all costs in Ukraine's IT outsourcing) will be } 17.5 \% \text {. } \\
\text { The effect of reducing total costs will be } 7.5 \% \text {. } \\
\text { Reasons: transfer of } 30 \% \text { of staff to remote work, arrangement of office space } \\
\text { without fixed working desks (free working place in the office) }\end{array}$ \\
\hline 3.2 & $\begin{array}{l}\text { Reduction of staff training costs (by } 65 \% \\
\text { compared to 2018-2019) }\end{array}$ & $\begin{array}{l}\text { Reduction of staff training costs by } 65 \% \text {. } \\
\text { The total share of staff training programs among all costs in Ukraine's IT } \\
\text { outsourcing in } 2018-2019 \text { was } 8 \% \text {. } \\
\text { After reducing this category's costs by } 65 \% \text {, this indicator (the total share of staff } \\
\text { training programs among all costs in Ukraine's IT outsourcing) will be } 2.8 \% \text {. } \\
\text { The effect of reducing total costs will be } 5.2 \% \text {. } \\
\text { Reasons: a need for cost optimization, an ability to operate due to the workforce's } \\
\text { actual potential (without additional training during the financial forecast year) }\end{array}$ \\
\hline
\end{tabular}


try. In particular, the author rightly suggests that these costs can be reduced by $30 \%$ (the number of staff, who were transferred to remote work in Ukraine). It should also be noted that the proposal to reduce the cost of staff training programs by $65 \%$ compared to the previous year is high, but does not threaten the loss of innovative development level of the subjects of this area, their products (services), and so on. At the same time, it should be noted that the author does not assume a possibility of the market's volume being reduced after the successful implementation of all these optimization's steps. This statement is quite debatable, because, in our opinion, the growth of outsourcing company in the Ukrainian IT industry depends on the customers' stability and economic activity. Given the current forecast trends in the economy, the IT outsourcing market in Ukraine will show a reduction, which will be reduced due to the main optimization initiatives. Although, these company forecasts for optimization costs can be taken as having a high level of reliability and feasibility, it should be noted that the researcher uses the method of cost optimization when formulating optimization steps.

Secondly, we should consider prospects of integration development for outsourcing companies in the Ukrainian IT industry, defined in the studies by M. Glova [5], M. Varkholinsky [6], D. Tapper [7] on this market's integration in the world market. It should be noted that the mentioned authors do not determine the order and options of such integration processes, forms of integration, approaches to the distribution of functional load. We shall determine the main composition's characteristics of outsourcing companies in the Ukrainian IT industry as of 31.12.2019 (Table 2) [8, 9].

The study on the research results (Table 2) showed that as of 31.12.2019 in Ukraine there functioned:

- twelve national majors (two are involved in traditional IT outsourcing in the field of software development for the business environment and ten are in traditional IT outsourcing in the field of software development for the business environment and new types of IT outsourcing based on use of cloud resources);

- six large foreign companies, one hundred of which are medium national ones and three thousand five hundred are small outsourcing companies in the field of IT in Ukraine (all three categories are involved in two types of IT outsourcing).

It should be noted that the main share of revenues of the global IT outsourcing market in Ukraine is received by large companies (75\% of revenues), $20 \%$ - by medium-sized market participants and $5 \%$ - by small ones. It is revealed that the traditional IT outsourcing in the field of software development for the business environment accounts for the main share of revenues of these entities (at the level of 80 to $95 \%$ of the volume of these entities), new types of IT outsourcing (cloud resources) - from 5 to $20 \%$ of the volume. The analysis revealed that about 15000 employees work at large national IT outsourcing companies in Ukraine. Regarding the existence of integration processes among the participants of the IT outsourcing market, there should be noted the existence of informal associations - territorial clusters. It was found that there are twenty IT clusters in Lviv, Lutsk, Ivano-Frankivsk, Ternopil, Khmelnytskyi, Chernivtsi, Rivne, Zhytomyr, Vinnytsia, Odesa, Mykolaiv, Zhovti Vody, Cherkasy, Kyiv, Chernihiv, Konotop, Sumy, Kharkiv, Severodonetsk, Zaporizhzhia, Mariupol, Dnipro. Although these cluster associations operate without the creation of legal regulation of relations, the subjects of territorial IT infrastructures ensure the functioning of local economies, provide employment to the population of these cities, suburban areas, and so on. In case of implementation of the forecast on reducing market participants in IT outsourcing (in the field of traditional activities, in particular, software) through a focus on cooperation with one performer instead of several as was popular and common in previous years. In our opinion, integration processes are a very real prospect, because with their help it is possible to overcome the crisis, to create a scale effect from the union of market participants. Guided by the provisions of scientific works, analytical research studies $[5,6]$, it can be stated that among the options for promising integrations in this area the following can be considered:

1) takeovers of small and medium market participants by large outsourcing companies in the field of IT. In this case, this integration can be associated with the sale of shares by business owners (medium and small companies) [7], and with the entry of the latter into the shareholders structure of the newly formed associations;

2) creation of network integration structures, within which the participants of the IT industry will operate both on the terms of legal independence (in accordance with the provisions of the cooperation agreement) and on the terms of creating a single centralized enterprise with appropriate participants, each of which aims to finish certain tasks. Network IT structures can consist of territorial participants (some of the considered large outsourcing IT companies operate today) [10] or can also be formed based on specialization (within one network IT structure, different IT companies that have the resources, experience, customer base in certain areas can be combined). The creation of network structures in IT outsourcing has many prospects in terms of the development of its new types (in the field of cloud resources) and optimization of the traditional structures;

3) creation of associations of enterprises, organizations and institutions that will operate on the terms of partnership cooperation (Jelonek, D. (2011). Koopetycja przedsiębiorstw informatycznych. Prace Naukowe Uniwersytetu Ekonomicznego we Wrocławiu.) within certain territories; According to the supporters of introduction of this form (Jelonek, 2011) [11, 12], cooperation is a modified form of competition and cooperation between market participants in the IT industry (including IT outsourcing). This form of integration has been comprehensively developed by Polish scientists. Following the provisions of this theory (Jelonek, 2011) [11, 12], it is possible to offer the scheme of integration of subjects of the market of IT-outsourcing of Ukraine on conditions of association in the form of cooperation (Table 3) (Jelonek, 2011) [11, 12].

Within the framework of the proposed Ukrainian IT outsourcing subject integration $[13,14]$ forecast scheme of unification in the form of cooperation $[15,16]$, the following stages are defined:

1) the stage of decision-making on the creation of an integrated structure on the terms of the association in the form of cooperation by large outsourcing IT companies;

2) the stage of partners selection (among large, medium and small outsourced IT companies);

3) the stage of accepting the order of interaction between all partners. The interaction order at the level of each of the categories of participants is determined. Within the framework of this partnership a fair distribution of functional loads is used (large partners receive large projects, distribute them among other participants (large, medium and small ones) depending on their characteristics [17, 18]; medium partners - between medium, small ones; small partners - at the appropriate level, among small subjects of the association;

4) the stage of organizing interaction on the terms of cooperation partnership;

5) the stage of evaluating the partnership's effectiveness on the terms of cooperation.

It should be noted that the creation and implementation of this type of integration associations is aimed at increasing the added economic value of their members, and, accordingly, increase capital $[19,20]$. Therefore, the implementation of this proposal can be used as one of the mobilization ways of the Ukrainian IT outsourcing market's capital growth.

Conclusions. The study on scientific approaches, views of researchers allowed systematizing and characterizing the list of ways to ensure the predictive efficiency of resource potential, 
The main characteristics of the composition of participants in the IT outsourcing market in Ukraine as of 31.12.2019

\begin{tabular}{|c|c|c|}
\hline No. & Category/name of IT outsourcing entity & $\begin{array}{l}\text { Characteristics, quantitative indicators of the } \\
\text { Ukrainian IT outsourcing market }\end{array}$ \\
\hline 1 & Major IT outsourcing companies, including: & $75 \%$ of the market \\
\hline 1.1 & 12 national market participants & \\
\hline 1.1 .1 & $\begin{array}{l}\mathrm{N} \text {-iX Company (Lviv, Ukraine), types of activity - traditional IT outsourcing in the } \\
\text { field of software development for businesses }\end{array}$ & 1000 employees \\
\hline 1.1 .2 & $\begin{array}{l}\text { Intellias Company (Lviv, Ukraine), types of activity - traditional IT outsourcing in } \\
\text { the field of software development for businesses) }\end{array}$ & 1500 employees \\
\hline 1.1 .3 & $\begin{array}{l}\text { SoftServe Company (Lviv, Ukraine), types of activity - traditional IT outsourcing } \\
\text { in the field of software development for businesses, public sector }(90 \%) \text {, new types } \\
\text { of IT outsourcing based on the use of cloud resources }(10 \%)\end{array}$ & 1500 employees \\
\hline 1.1.4 & $\begin{array}{l}\text { Ciklum Company (Kyiv, Ukraine), types of activity - traditional IT outsourcing in } \\
\text { the field of software development for businesses, public sector }(80 \%) \text {, new types of } \\
\text { IT outsourcing based on the use of cloud resources }(20 \%)\end{array}$ & 2700 employees \\
\hline 1.1.5 & $\begin{array}{l}\text { Infopulse Company (Kyiv, Ukraine), types of activity }- \text { traditional IT outsourcing } \\
\text { in the field of software development for businesses, public sector }(95 \%) \text {, new types } \\
\text { of IT outsourcing based on the use of cloud resources }(5 \%)\end{array}$ & 1500 employees \\
\hline 1.1.6 & $\begin{array}{l}\text { Eleks Company (Lviv, Ukraine), types of activity - traditional IT outsourcing in the } \\
\text { field of software development for businesses, public sector }(85 \%) \text {, new types of IT } \\
\text { outsourcing based on the use of cloud resources }(15 \%)\end{array}$ & 1000 employees \\
\hline 1.1 .7 & $\begin{array}{l}\text { Sigma Software (Kharkiv, Ukraine), types of activity - traditional IT outsourcing in } \\
\text { the field of software development for businesses, public sector }(90 \%) \text {, new types of } \\
\text { IT outsourcing based on the use of cloud resources }(10 \%)\end{array}$ & 1500 employees \\
\hline 1.1.8 & $\begin{array}{l}\text { Miratech (Kyiv, Ukraine), types of activity - traditional IT outsourcing in the field } \\
\text { of software development for businesses, public sector }(91 \%) \text {, new types of IT } \\
\text { outsourcing based on the use of cloud resources }(9 \%)\end{array}$ & 1500 employees \\
\hline 1.1 .9 & $\begin{array}{l}\text { Innovecs (Kyiv, Ukraine), types of activity - traditional IT outsourcing in the field } \\
\text { of software development for businesses, public sector }(88 \%) \text {, new types of IT } \\
\text { outsourcing based on the use of cloud resources }(12 \%)\end{array}$ & 1000 employees \\
\hline 1.1.10 & $\begin{array}{l}\text { AMC Bridge (Dnipro, Ukraine), types of activity - traditional IT outsourcing in } \\
\text { the field of software development for businesses, public sector }(95 \%) \text {, new types of } \\
\text { IT outsourcing based on the use of cloud resources }(5 \%)\end{array}$ & 800 employees \\
\hline 1.1 .11 & $\begin{array}{l}\text { Softengi Company (Kyiv, Ukraine), types of activity - traditional IT outsourcing in } \\
\text { the field of software development for businesses, public sector }(90 \%) \text {, new types of } \\
\text { IT outsourcing based on the use of cloud resources }(10 \%)\end{array}$ & 800 employees \\
\hline 1.1 .12 & $\begin{array}{l}\text { Program-Ace Company (Kharkiv, Ukraine), types of activity - traditional IT } \\
\text { outsourcing in the field of software development for businesses, public sector }(95 \%) \text {, } \\
\text { new types of IT outsourcing based on the use of cloud resources }(5 \%)\end{array}$ & 200 employees \\
\hline 1.2 & $\begin{array}{l}\text { Foreign IT outsourcing companies with offices in Ukraine. Types of activity - tradi- } \\
\text { tional IT outsourcing in the field of software development for businesses, public sector } \\
(90 \%) \text {, new types of IT outsourcing based on the use of cloud resources }(10 \%)\end{array}$ & 6 subjects of the market environment \\
\hline 2 & $\begin{array}{l}\text { Medium IT outsourcing companies. Types of activity - traditional IT outsourcing } \\
\text { in the field of software development for businesses, public sector }(90 \%) \text {, new types } \\
\text { of IT outsourcing based on the use of cloud resources }(10 \%)\end{array}$ & $\begin{array}{l}100 \text { subjects of the market environment } \\
\text { ( } 20 \% \text { of the market) }\end{array}$ \\
\hline 3 & $\begin{array}{l}\text { Small outsourcing companies in the field of IT. Types of activity - traditional IT } \\
\text { outsourcing in the field of software development for businesses, public sector } \\
(90 \%) \text {, new types of IT outsourcing based on the use of cloud resources }(10 \%)\end{array}$ & $\begin{array}{l}3500 \text { subjects of the market environment } \\
\text { ( } 5 \% \text { of the market) }\end{array}$ \\
\hline 4 & Research laboratories & $\begin{array}{l}5 \text { organizations, including one (Fabricator) which } \\
\text { is a representative of a foreign company named } \\
\text { Fablab, and four being Ukrainian residents. They } \\
\text { collaborate with large outsourcing companies in the } \\
\text { field of IT in the direction of certain developments }\end{array}$ \\
\hline 5 & Research and development centers & $\begin{array}{l}110 \text { subjects of the market environment. Operate } \\
\text { in the field of IT, perform certain IT outsourcing } \\
\text { contracts }\end{array}$ \\
\hline 6 & $\begin{array}{l}\text { Number of educational institutions in the field of information technologies in } \\
\text { Ukraine }\end{array}$ & $\begin{array}{l}200 \text { institutions, including } 12 \text { large private } \\
\text { educational organizations }\end{array}$ \\
\hline 7 & IT clusters & $\begin{array}{l}\text { Created in } 20 \text { cities of Ukraine (Lviv, Lutsk, } \\
\text { Ivano-Frankivsk, Ternopil, Khmelnytskyi, } \\
\text { Chernivtsi, Rivne, Zhytomyr, Vinnytsia, Odesa, } \\
\text { Mykolaiv, Zhovti Vody, Cherkasy, Kyiv, Chernihiv, } \\
\text { Konotop, Sumy, Kharkiv, Severodonetsk, } \\
\text { Zaporizhzhia, Mariupol, Dnipro) with an } \\
\text { infrastructure being formed. Clusters operate on } \\
\text { the terms of participants' legal independence }\end{array}$ \\
\hline
\end{tabular}


Integration forecast scheme for Ukrainian outsourcing IT subjects of unification in the form of cooperation

\begin{tabular}{|c|c|c|}
\hline No. & Stage/indicator & Characteristic \\
\hline 1 & $\begin{array}{l}\text { Decision-making on creation of an } \\
\text { integrated structure on the terms of } \\
\text { unification in the form of } \\
\text { cooperation by large outsourcing } \\
\text { IT companies }\end{array}$ & $\begin{array}{l}\text { Does not include the creation of a joint legal entity, decentralization. } \\
\text { Cooperation is declared on contractual terms }\end{array}$ \\
\hline 2 & Partners selection, including: & \\
\hline 2.1 & $\begin{array}{l}\text { Among large IT outsourcing } \\
\text { companies }\end{array}$ & $\begin{array}{l}\text { Reasons for involvement in cooperation: if necessary, expansion of activities. } \\
\text { Criteria for attracting the following category of partners: } \\
\text { - partner consent (large IT outsourcing companies); } \\
\text { - economic efficiency, the existence of additional economic value of promising partner companies. } \\
\text { The assessment is based on financial statistical statements }\end{array}$ \\
\hline 2.2 & $\begin{array}{l}\text { Among medium IT outsourcing } \\
\text { companies }\end{array}$ & $\begin{array}{l}\text { Reasons for involvement in cooperation: } \\
\text { - expansion of activity volumes if needed; } \\
\text { - if necessary, involving the partners who have high competencies in a particular field (efficiency } \\
\text { in a narrow specialization). } \\
\text { Criteria for attracting the above-mentioned category of partners: } \\
\text { - partner consent (medium-sized IT outsourcing companies); } \\
\text { - economic efficiency, the existence of additional economic value of promising partner companies. } \\
\text { The assessment is based on financial statistical reporting; } \\
\text { - additional parameters. Such parameters can be an expert assessment of certain areas of activity } \\
\text { (personnel, technical, information, financial and economic policy, security policy, and so on) }\end{array}$ \\
\hline 2.3 & $\begin{array}{l}\text { Among small IT outsourcing } \\
\text { companies }\end{array}$ & $\begin{array}{l}\text { Reasons for involvement in cooperation: } \\
\text { - expansion of activity volumes if needed; } \\
\text { - if necessary, involving the partners who have high competencies in a particular field (efficiency } \\
\text { in a narrow specialization). } \\
\text { Criteria for attracting the above-mentioned category of partners: } \\
\text { - partner consent (small IT outsourcing companies); } \\
\text { - economic efficiency, the existence of additional economic value of promising partner } \\
\text { companies. The assessment is based on financial statistical reporting; } \\
\text { - additional parameters. Such parameters can be an expert assessment of certain areas of activity } \\
\text { (personnel, technical, information, financial and economic policy, security policy, and others) }\end{array}$ \\
\hline 3 & $\begin{array}{l}\text { Adoption of association members } \\
\text { interaction order }\end{array}$ & \\
\hline 3.1 & $\begin{array}{l}\text { Large projects are accepted by large } \\
\text { structural participants }\end{array}$ & $\begin{array}{l}\text { Decision-making on: } \\
\text { - distribution of functional load on internal divisions; } \\
\text { - redistribution of certain tasks, directions of the specified projects to the association's average } \\
\text { structural participants; } \\
\text { - redistribution of certain narrow-profile tasks among medium-sized, small structural participants } \\
\text { who specialize in their implementation; } \\
\text { - redistribution of certain standard tasks among medium, small structural participants }\end{array}$ \\
\hline 3.2 & $\begin{array}{l}\text { Medium projects are accepted by } \\
\text { medium structural participants }\end{array}$ & $\begin{array}{l}\text { Decision-making on: } \\
\text { - distribution of functional load on internal divisions; } \\
\text { - redistribution of certain tasks, directions of the specified projects to the association's average } \\
\text { structural participants; } \\
\text { - redistribution of certain narrow-profile tasks among medium-sized, small structural participants } \\
\text { who specialize in their implementation; } \\
\text { - redistribution of certain standard tasks among medium, small structural participants }\end{array}$ \\
\hline 3.3 & $\begin{array}{l}\text { Small projects are accepted by } \\
\text { small structural participants }\end{array}$ & $\begin{array}{l}\text { Decision-making on: } \\
\text { - distribution of functional load on internal divisions; } \\
\text { - redistribution of certain tasks, directions of the specified projects to the association's average } \\
\text { structural participants; } \\
\text { - redistribution of certain narrow-profile tasks among medium-sized, small structural } \\
\text { participants who specialize in their implementation; } \\
\text { - redistribution of certain standard tasks among small structural participants }\end{array}$ \\
\hline 4 & $\begin{array}{l}\text { Organization of interaction on the } \\
\text { terms of cooperation partnership }\end{array}$ & $\begin{array}{l}\text { Within certain regional frameworks, by certain types of IT outsourcing, certain segments of } \\
\text { customer clients (regional, specific, and so on) }\end{array}$ \\
\hline 5 & $\begin{array}{l}\text { Evaluation of the partnership } \\
\text { effectiveness on the terms of } \\
\text { cooperation }\end{array}$ & $\begin{array}{l}\text { Evaluation of the partner association at the general level: } \\
\text { - effect of changes in participants' market share; } \\
\text { - effect of the association's international integration; } \\
\text { - effect of innovative development (by parametric indicators); } \\
\text { - economic effect at the general level, at the level of each of the participants. The change in } \\
\text { additional economic value is determined by the results of joint work. } \\
\text { The results of the evaluation determine the advantages, problems and ways to improve. } \\
\text { If necessary, a decision is made on the exit (entry) of a partner. }\end{array}$ \\
\hline
\end{tabular}


innovative development of outsourcing IT companies in Ukraine, including:

1) maintaining operational efficiency by optimizing the functional load on staff (redistribution of tasks in accordance with the working experience);

2) maintaining operational efficiency by optimizing the form of interaction with customers (promotion and partnership negotiations in remote forms);

3) reduction of indirect costs of companies (reduction of rental costs, reduction of staff training costs).

These development paths are related to ensuring a direct impact on the preservation of net income, growth of net profit and equity.

The authors also identified the main characteristics of the Ukrainian IT outsourcing market's participants. In the course of this analysis, options for promising integrations of IT outsourcing entities were proposed as a separate way to optimize innovative indicators of outsourcing companies:

1) takeovers of medium and small market participants by large outsourcing companies in the field of IT;

2) creation of network integration structures, within which the participants of the IT industry will operate both on the terms of legal independence and on the terms of creating a single centralized enterprise;

3) creation of associations of enterprises, organizations and institutions that will operate on the terms of partnership cooperation within certain territories.

The Ukrainian IT outsourcing subject integration forecast scheme of unification in the form of cooperation was also defined and offered.

The introduction of optimization ways for the activities of IT outsourcing entities is substantiated, perspective efficiency of innovative development in accordance with the defined directions is determined, thoroughness of the methodology is proved.

\section{References.}

1. Altynpara, A., \& Korogodova, O. (2019). Outsourcing as a tool for the development of companies in the IT sector in terms of Industry - 4.0. Economic Bulletin of NTUU "KPI", 16, 140-152.

2. Verba, A. (2020). What will happen to the Ukrainian IT market after the pandemic. Retrieved from_https://nv.ua/biz/experts/rynok-it-karantin-i-pandemiya-koronavirusa-k-chemu-gotovitsya-tehnologicheskim-kompaniyam-novostiukrainy-50084249.html.

3. Volkova, N., Kolesnik, E., \& Silina, I. (2017). Place of Ukraine in the world IT outsourcing market: analysis of state and prospects. Innovative development of the economy: entrepreneurship, education, science, 30-33.

4. Meshko, N., \& Kostyuchenko, M. (2015). Prospects for the development of IT as a leading innovation industry in Ukraine. Bulletin of Dnipropetrovsk University: Innovation Management Series, 4, 71-77.

5. Hlova, M. (2020). Top 5 IT outsourcing trends that will rule in 2020. Retrieved from https://www.n-ix.com/top-it-outsourcing-trends-rule/.

6. Warcholinski, M. (2020). Top IT Outsourcing Trends for +2020. Retrieved from https://brainhub.eu/blog/it-outsourcing-trends-2020/.

7. Tapper, D. (2020). Worldwide and U.S. IT Outsourcing Services Forecast, 2020-2024. Retrieved from https://www.idc. com/getdoc.jsp? containerId=US45109420.

8. Sudolsky, R., \& Smyrnov, D. (Eds.) (2019). Tech ecosystem guide to Ukraine. Kyiv: Unit. city. Retrieved from https://data. unit.city/tech-guide/Tech_Ecosystem_Guide_To_Ukraine_ En-1.1.pdf.

9. 18 Ukrainian outsourcing companies which were included in the world TOP-100. Retrieved from https://dou.ua/lenta/ news/outsourcing-top-100-2018/.

10. Yaremchuk, R. (2015). The main advantages and threats to the integrated development of the IT sector of Ukraine from the implementation of the Association Agreement with the EU. Social-economic problems of the modern period of Ukraine, 5, 68-72.

11. Bura, K. (2020). Toward the Definition of Multimodal Argumentation. Future Human Image, 14, 4-12. https://doi. org/10.29202/fhi/14/1.

12. Zakrzewska-Bielawska, A. (2014). Coopetition in the development of high-tech enterprises. Determinants and dynamics. Warsaw: Placet.

13. Bezzubov, D., \& Pravotorova, O. (2020). The Impact of Transnational Corporations on the Regulatory Framework for the World Market for Space Services and Technologies. $A d-$ vanced Space Law, 6, 4-12.

14. Bilan, Y., Nitsenko, V., Ushkarenko, I., Chmut, A., \& Sharapa, O. (2017). Outsourcing in international economic relations. Montenegrin Journal of Economics, 13(3), 175-185. https://doi.org/10.14254/1800-5845/2017.13-3.14.

15. Piliaiev, I. (2019). The Value Dichotomy Curse of Ukraine's Modernization: to Break, or not to Be. Ukrainian Policymaker, 5, 68-76. https://doi.org/10.29202/up/5/8.

16. Raišienè, A. G., Yatsenko, O., Nitsenko, V., Karasova, N., \& Vojtovicova, A. (2019). Global dominants of Chinese trade policy development: Opportunities and threats for cooperation with Ukraine. Journal of International Studies, 12(1), 193207. https://doi.org/10.14254/2071-8330.2019/12-1/13.

17. Kondarevych, V., Andriushchenko, K., Pokotylska, N., Ortina, G., Zborovska, O., \& Budnyak, L. (2020). Digital Transformation of Business Processes of an Enterprise. TEM Journal, 9(4), 1800-1808. https://doi.org/10.18421/TEM94-63.

18. Nitsenko, V., Kotenko, S., Hanzhurenko, I., Mardani, A., Stashkevych, I., \& Karakai, M. (2020). Mathematical Modeling of Multimodal Transportation Risks. In: Ghazali, R., Nawi, N., Deris, M., \& Abawajy, J. (Eds.). Recent Advances on Soft Computing and Data Mining. SCDM 2020. Advances in Intelligent Systems and Computing, (pp. 439-447). Springer, Cham. https://doi.org/10.1007/978-3-030-36056-6 41.

19. Andriushchenko, K., Buriachenko, A., Rozhko, O., Lavruk, O., Skok, P., Hlushchenko, Y., ..., \& Kondarevych, V. (2020). Peculiarities of sustainable development of enterprises in the context of digital transformation. Entrepreneurship and Sustainability Issues, 7(3), 2255-2270. https://doi.org/10.9770/ jesi.2020.7.3(53).

20. Kucher, A., Mendrukh, Y., Khodakevich, O., \& Dybkova, L. (2019). Management of formation of communicative competence of the future economists: case study of Ukraine. TEM Journal, 8(4), 1127-1136. https://doi.org/10.18421/TEM84-04.

\section{Мобілізація інноваційних і ресурсних факторів розвитку національних аутсорсингових компаній у сфері IT}

\section{Т. М. Циганкова ${ }^{1}$, О. М. Яценко ${ }^{1}$ О. М. Мозговий ${ }^{1}$, Т. М.Дідух}

1 - Київський національний економічний університет імені Вадима Гетьмана, м. Київ, Україна, е-mail: yacenkoolgakneu@gmail.com

2 - PPRO Financial ltd, м. Мюнхен, Федеративна Республіка Німеччина

3 - CyberVision Inc, м. Київ, Україна

Мета. Систематизувати та обгрунтувати оптимізаційні шляхи мобілізації внутрішнього ресурсного потенціалу та інноваційних показників розвитку аутсорсингових компаній у сфері IT в Україні.

Методика. Для зазначених цілей було проведено методичне обгрунтування прогнозування на основі використання наступних методів: методу трендів (встановлення прогнозних показників розвитку на підставі визначення середнього тренду попередніх періодів) для 
визначення й систематизації шляхів забезпечення прогнозної ефективності ресурсного потенціалу, інноваційного розвитку аутсорсингових компаній у сфері IT; порівняльного та статистичного методів (застосування методів для аналізу звітних даних, порівняння їх із прогнозними) та методу прогнозування (здійснення прогнозування за основними кількісними та якісними показниками) для визначення порівняльної характеристики даних шляхів; геометричного методу прямої залежності змін (визначення рівня залежності змін, розрахованого методом прямої геометричної прогресії) для оцінки ефективності прогнозної схеми інтеграції суб'єктів ринку IT-аутсорсингу України на умовах об'єднання у формі коопетиції.

Результати. Досліджені та обгрунтовані основні шляхи оптимізації ресурсного потенціалу, інноваційних показників розвитку аутсорсингових компаній у сфері IT в Україні. Систематизація наукових підходів, поглядів дослідників дозволила сформувати перелік оптимізаційних шляхів розвитку цих компаній.

Наукова новизна. Уперше запропонована організаційно-економічна форма інтеграції суб'єктів ринку ITаутсорсингу України як шлях оптимізації ресурсного потенціалу на умовах об'єднання у формі коопетиції, що передбачає забезпечення функціонування конкурентних структур різних категорій, основане на співпраці й партнерстві стосовно роботи 3 клієнтами, перерозподілу функціональних навантажень, створення додаткових ринкових економічних ефектів, можливому вирішенні соціально-економічних завдань регіонів.

Практична значимість. Полягає в розробці та апробації методичного інструментарію, призначеного для експрес-оцінки рівня розвитку інноваційно-ресурсного потенціалу діяльності IT-підприємств. Результати дослідження можуть бути використані національними компаніями IT-аутсорсингу з метою росту капіталу та збереження операційної ефективності, з метою забезпечення функціонування конкурентних структур різних категорій, націлених на зростання доданої економічної вартості їх учасників.

Ключові слова: IT-аутсорсинг, інформаційні технологіï, IT-аутсорсингові компанії, ресурсний потенціал ITсфери

\section{Мобилизация инновационных и ресурсных факторов развития национальных аутсорсинговых компаний в сфере IT}

\section{T. М. Цыганкова ${ }^{1}$, О. М. Яиенко ${ }^{1}$, О. М. Мозговой Т. М.Дидух $x^{2}$ Л. В. Пацёла}

1 - Киевский национальный экономический университет имени Вадима Гетьмана, г. Киев, Украина, e-mail: yacenkoolgakneu@gmail.com

2 - PPRO Financial ltd, г. Мюнхен, Федеративная Республика Германия

3 - CyberVision Inc, г. Киев, Украина
Цель. Систематизировать и обосновать оптимизационные пути мобилизации внутреннего ресурсного потенциала и инновационных показателей развития аутсорсинговых компаний в сфере IT в Украине.

Методика. Для указанных целей было проведено методическое обоснование прогнозирования на основе использования следующих методов: метода трендов (установление прогнозных показателей развития на основании определения среднего тренда предыдущих периодов) для определения и систематизации путей обеспечения прогнозной эффективности ресурсного потенциала, инновационного развития аутсорсинговых компаний в сфере IT; сравнительного и статистического методов (применение методов для анализа отчетных данных, сравнение их с прогнозными) и метода прогнозирования (осуществление прогнозирования по основным количественным и качественным показателям) для определения сравнительной характеристики указанных выше путей развития; геометрического метода прямой зависимости изменений (определение уровня зависимости изменений, рассчитанного методом прямой геометрической прогрессии) для оценки эффективности прогнозной схемы интеграции субъектов рынка IT-аутсорсинга Украины на условиях объединения в форме коопетиции.

Результаты. Исследованы и обоснованы основные пути оптимизации ресурсного потенциала, инновационных показателей развития аутсорсинговых компаний в сфере IT в Украине. Систематизация научных подходов, взглядов исследователей позволила сформировать перечень оптимизационных путей развития этих компаний.

Научная новизна. Впервые предложена организационно-экономическая форма интеграции субъектов рынка IT-аутсорсинга Украины как путь оптимизации ресурсного потенциала на условиях объединения в форме коопетиции, которая предусматривает обеспечение функционирования конкурентных структур различных категорий, основанного на сотрудничестве и партнерстве по работе с клиентами, перераспределения функциональных нагрузок, создание дополнительных рыночных экономических эффектов, возможном решении социально-экономических задач регионов.

Практическая значимость. Заключается в разработке и апробации методического инструментария, предназначенного для экспресс-оценки уровня развития инновационно-ресурсного потенциала деятельности IT-предприятий. Результаты исследования могут быть использованы национальными компаниями IT-аутсорсинга с целью роста капитала и сохранения операционной эффективности, в целях обеспечения функционирования конкурентных структур различных категорий, нацеленных на рост добавленной экономической стоимости их участников.

Ключевые слова: IT-аутсорсинг, информационные технологии, IT-аутсорсинговые компании, ресурсный потенциал IT-сферы

Recommended for publication by M. Sahaidak, Doctor of Economic Sciences. The manuscript was submitted 17.08.20. 